\title{
Ewelina Sudra
}

\section{Uwarunkowania społeczno-kulturowe postaw przedsiębiorczych młodzieży z obszarów wiejskich}

\section{Wstęp}

W pracach większości autorów dominuje rozumienie przedsiębiorczości w kontekście prawno-ekonomicznym. Określana jest ona jako proces zakładania działalności gospodarczej. Przedsiębiorczość ujmowana jest także poprzez pryzmat cech osobowościowych. W niniejszym artykule przytoczone zostały rozważania obecne w literaturze przedmiotu na temat uwarunkowań społeczno-kulturowych przedsiębiorczości definiowanej jako zbiór cech osobowościowych. Spośród czynników warunkujących postawę przedsiębiorczą wybrano do analizy rodzinę, edukację i kulturę. Szczególną uwagę zwraca się na diagnozę uwarunkowań rozwoju postawy przedsiębiorczej młodzieży wiejskiej. Potencjał młodych mieszkańców wsi w tym zakresie odgrywać może dużą rolę w rozwoju obszarów wiejskich. Podejmując badania postaw przedsiębiorczych młodzieży wiejskiej należy wziąć pod uwagę rozpatrywane poniżej uwarunkowania ${ }^{1}$.

\section{Istota przedsiębiorczości}

Przedsiębiorczość nie jest zjawiskiem nowym. Badaniem jej aspektów zajmują się różnorodne dziedziny naukowe. Niebagatelny wpływ na

1 Przegląd literaturowy dotyczący uwarunkowań postaw przedsiębiorczych młodzieży, w tym młodzieży wiejskiej, jest punktem wyjścia badań planowanych w tym zakresie przez autorkę artykułu. Będą one wykorzystane w rozprawie doktorskiej pt. Przejawy i uwarunkowania postaw przedsiębiorczych młodzieży wiejskiej. 
zdefiniowanie tego pojęcia miały nauki ekonomiczne. Termin ,przedsiębiorczość" wprowadził francuski ekonomista R. Cantillona, który wiązał je z poczuciem niepewności, z podejmowaniem ryzyka przy zakładaniu własnej działalności gospodarczej (Duraj, Papiernik-Wojdera 2010: 11). Na ukształtowanie się tego pojęcia miały wpływ trzy ważne postacie. Pierwsza z nich to F. Knight, który wiązał przedsiębiorczość ze zdolnością do podejmowania ryzyka. Uważał on, że bez ryzyka i niepewności nie ma przedsiębiorczości. Osoba, która wykazuje skłonność do ryzykowania, chętniej założy własną działalność gospodarczą niż osoba, która takiej skłonności nie ma. Ta ostatnia woli zostać pracownikiem, otrzymującym miesięcznie stałe wynagrodzenie, co jest sytuacją całkowicie pozbawioną ryzyka (Gaweł 2007: 15). Wspomniany autor rozróżniał niepewność od ryzyka. Tę pierwszą traktował jako stan nieoczekiwany, którego nie można przewidzieć. Ryzyko, jego zdaniem, było odchyleniem od stanu oczekiwanego, które można przewidzieć. Interesowała go też rola zysku w działaniach przedsiębiorczych. Na zysk przedsiębiorcy składają się takie czynniki, jak specyficzne umiejętności, szczęście oraz sytuacja na rynku (Piecuch 2013: 30-31). Za twórcę podwalin przedsiębiorczości uznaje się J. Schumpetera, który definiował ją jako ,proces twórczej destrukcji, w wyniku której powstają nowe kombinacje w sferze wytwarzania, będące zalążkiem działań przedsiębiorczych" (Schumpeter 1990: 104). Wychodził on naprzeciw zbiurokratyzowanemu zarządzaniu. Przedsiębiorczość miała zaburzać, wprowadzać kontrolowany chaos w strukturach rynkowych (Gabińska 2012: 261). Przedsiębiorcę charakteryzuje „zmysł przedsiębiorczości”, który odgrywa istotną rolę w „twórczej destrukcji”, czyli w powstawaniu i rozwoju gospodarki, „nowych kombinacji” będących zalążkiem działań przedsiębiorczych. Według niego przedsiębiorca to kreatywny niszczyciel, który tworzy

poprzez unicestwienie (dokonuje twórczej destrukcji właśnie). Uprawia coś, co brzydko nazywa „technicznym lub produkcyjnym kanibalizmem”, a co polega na zastępowaniu jeszcze sprawnych maszyn, produktów i usług innymi, bardziej sprawnymi, często działającymi na zupełnie innej zasadzie (Kwiatkowski 1993: 11, za: Piecuch 2013: 25). 
Poglądy ekonomisty są aktualne do dziś i poddawane różnych osądom. W kontekście przedsiębiorczości przytacza się także nazwisko I. Kirznera, który wywodził się ze szkoły austriackiej. W jego ujęciu przedsiębiorczość jest utożsamiana $\mathrm{z}$ odkrywaniem informacji bądź umiejętnością identyfikacji i wykorzystania możliwości rynkowych (Gabińska 2012: 262). Kirzner pojmował przedsiębiorczość dwojako, wiążąc ją z perspektywą horyzontu czasu. W krótkim okresie, przedsiębiorczość identyfikował z wykorzystywaniem szans na rynku i dostosowywaniem się do aktualnych potrzeb i oczekiwań klientów. W długim okresie kładł nacisk na odkrywanie nowych możliwości, wprowadzanie innowacji. Wszystkie przemyślenia ekonomisty koncentrowały się wokół zysku osiaganego przez przedsiębiorcę. Osiaganie zysku, nadzwyczajnych korzyści, jest jedną z najważniejszych umiejętności osoby przedsiębiorczej. Wspomniany autor traktował zysk jako wynagrodzenie za podejmowanie działań przedsiębiorczych. Tym samym jednak podkreślał brak zależności liniowej między wysoką przedsiębiorczością (wysokim zaangażowaniem, dużymi pokładami energii i kreatywności, inicjatywy, etc.) a wielkością zysku. Przedsiębiorcę wyposażał w szczególny rodzaj czujności, który umożliwia rozpoznawanie i wykorzystywanie szans pozwalających osiagnąć zysk (Piecuch 2013: 28-29).

W literaturze można się spotkać $\mathrm{z}$ dwoma ujęciami przedsiębiorczości - jako procesu, sposobu działania podejmowanego przez osoby zakładające działalność gospodarczą (ujęcie czynnościowe) oraz jako zbioru cech osobowościowych charakteryzujących postawę przedsiębiorczą (ujęcie atrybutywne). Pierwszy sposób definiowania został wypracowany przez nauki ekonomiczne, drugi zaś przez nauki psychologiczne i społeczne (Grzegorzewska-Mishka 2010: 17-18).

Pionierami ujmowania przedsiębiorczości jako procesu są, jak wspomniano, ekonomiści. Definiowali oni to zjawisko jako ciagła, dynamiczną aktywność, objawiającą się w działaniu. Ten procesualny charakter przedsiębiorczości przejawia się w jej następujących etapach: obserwacja otoczenia, pomysł, motywacja, środki realizacji, realizacja, efekt. Przedsiębiorczość jest tutaj procesem kolejnych, następujących po sobie etapów, polegającym na wykorzystaniu w określonych warunkach pomysłu innowacyjnego w celu osiagnięcia zysku. W fazie obserwacji 
otoczenia następuje identyfikacja szans, problemu. Pomysł innowacyjny to pomysł oryginalny, nietypowy, kreatywny. Z pomysłem innowacyjnym związana jest motywacja przedsiębiorcza, czyli chęć, pragnienie osiagnięcia korzyści z podejmowanej działalności. Przed wdrożeniem pomysłu w życie zbierane są środki na jego realizację. Mają one charakter zarówno materialny (zasoby finansowe), jak i niematerialny (zasoby społeczne). Dalej następuje najważniejsza faza przedsiębiorczości - realizacja pomysłu. Efektami procesu przedsiębiorczego są korzyści lub straty przedsiębiorcy (Adamczyk 1996: 25, za: Piecuch 2013: 44). W definicjach wielu teoretyków można odnaleźć procesualny charakter przedsiębiorczości. R. W. Griffin, znany teoretyk zarządzania, postrzega jąjako proces planowania, organizowania i prowadzenia działalności gospodarczej. Podobnie P. McGowan traktuje przedsiębiorczość jako proces, któremu towarzyszą twórcze myślenie, kreatywność, umiejętności planistyczne i organizacyjne. W kategoriach procesualnych postrzegaja przedsiębiorczość M. Bratnicki i J. Strużyna. Dla nich przedsiębiorczość to specyficzny proces działania oparty na dostrzeganiu, myśleniu, kreowaniu i wykorzystywaniu szans rozwojowych. Objawia się on w zachowaniach przedsiębiorczych polegających na ciagłym poszukiwaniu i wdrażaniu szans, organizacji otoczenia, planowania działań przedsiębiorczych i zespolenia ich we wzajemnej współpracy (Jamka 2012: 19, 21). Także J. D. Antoszkiewicz zdefiniował przedsiębiorczość jako proces, czyli działanie umożliwiające powstanie nowych wartości. U podstaw poczynań człowieka leżą pozytywne wartości, gdyż negatywne mogłyby doprowadzić do destrukcji przedsiębiorczości (Kapusta 2006: 22).

O postawie przedsiębiorczej najczęściej mówi się w kontekście podejścia atrybutywnego stosowanego w naukach społecznych. Postawę taką zwykło się charakteryzować poprzez wyróżnienie cech osobowościowych jednostki. Naukowcy podają wiele zestawień zawierających pożądane cechy osobowościowe, którymi wyróżniają się osoby przedsiębiorcze. Listę taką zaproponował na przykład A. Gibb. Wyróżnia on następujące wzorcowe cechy osobowościowe: komunikatywność, elastyczność, kreatywność, dar przekonywania, wyższą od przeciętnej skłonność do podejmowania ryzyka, ducha konkurencyjności, wyobraźnię, samodzielność, zdolność do rozwiązywania problemów i konfliktów, 
wiarę w możliwość kształtowania własnego losu, gotowość do ciężkiej pracy i do poszukiwania informacji. Innym przykładem takiego zbioru są cechy wskazane przez E. Chell: poszukiwanie okazji biznesowej, twórczość i pomysłowość, aktywność, dbanie o prestiż, innowacyjność, popieranie zmian (Bławat 2003: 50-51). Przeprowadzone wśród przedsiębiorców badania pozwoliły T. Piecuch (2013: 63) skompletować następujące cechy: kreatywność, twórczość, pomysłowość, konsekwencję w dążeniu do celu, uczciwość, odpowiedzialność, wiedzę fachową, kompetencje, umiejętność podejmowania decyzji; odwagę, asertywność, odpowiednią prezencję, silny charakter, opanowanie, komunikatywność, zaradność, operatywność, skłonność do podejmowania ryzyka, dyscyplinę pracy, pewność siebie, aktywność. O pożądanych cechach osobowościowych mówi również teoria pięciu cech („Wielkiej Piątki”) wyodrębnionych przez Costę i MacCrae. Autorzy ci wyróżnili następujące cechy: neurotyzm, ekstrawersję, sumienność, ugodowość i otwartość. Z kolei D. McClelland uważał, że główną cechą inicjującą działania przedsiębiorcze jest motywacja, która jest siłą, potrzebą osiągnięć. Interesującą teorią jest też koncepcja pasji przedsiębiorczej Cardona. Głównym motorem zachowań przedsiębiorczych jest według niej pasja, której towarzyszą pozytywne emocje, takie jak duma, entuzjazm czy radość. Jest ona również powiązana $\mathrm{z}$ motywacją, pomaga w pokonywaniu wszelkich trudności i utrzymaniu zaangażowania (Ratajczak 2012: 56).

W literaturze przedstawia się też cechy utrudniające przejawianie postaw przedsiębiorczych. Do takich ,cech antyprzedsiębiorczych” zalicza się głównie: nadmierną twardość bądź miękkość, czyli brak elastyczności, impulsywność, brak autorytetów, nadmierne poleganie na sile wyższej, niechęć do eliminacji swoich słabych stron, a także perfekcjonizm, który został zdefiniowany jako nadmierna troska o szczegóły (Glinka, Gudkova 2011: 128).

Tocząca się wokół cech osobowościowych jednostki przedsiębiorczej dyskusja dotyczy źródeł ich pochodzenia. Z jednej strony głos zabierają zwolennicy podejścia, że cechy te mają charakter wrodzony. Przedstawicielem tego nurtu jest np. L. H. Haber, dla którego idealnym typem cech osobowości przedsiębiorczej jest homo hubris. Osobę taką charakteryzuje wysoki poziom potrzeby osiagnięć, wysoka tolerancja 
ryzyka, pewność siebie, chęć podejmowania działań poszerzających jej możliwości fizyczne, intelektualne, manualne, umysłowe, pragnienie poznawania nowych zjawisk, przełamywanie barier i stereotypów (Haber 1997: 16, za: Piecuch 2013: 65). Inne stanowisko zajmują zwolennicy poglądu, że przedsiębiorczość można wykształcić, głównie w procesach socjalizacji i edukacji. Taki pogląd reprezentował m.in. P. F. Drucker. Uważał on, iż cechy osobowościowe mają charakter nabyty, można się więc ich nauczyć. Ponadto zachowaniami przedsiębiorczymi mogą wykazywać się jednostki o różnych cechach osobowościowych (Drucker 2004: 29). Zintegrowane podejście prezentuje natomiast L. Milian, który uważa, że przedsiębiorczość jest zarazem cechą wrodzoną, jak i nabytą. Jest pewną dyspozycją osobowościową, która warunkuje podjęcie działań przedsiębiorczych. Cechy wrodzone mogą zostać wzmocnione, wykształcone w procesie edukacji (Millian 2000: 10, 17).

W obrębie socjologii wyłoniła się subdyscyplina zwaną socjologią przedsiębiorczości, która bada oprócz ekonomicznego wymiaru przedsiębiorczości także jej symboliczny i kulturowy aspekt, w tym normy kulturowe, działania zbiorowe oraz solidarność grupową. Rozpatruje działania przedsiębiorcze nie tylko z perspektywy gospodarczej, ale również z perspektywy przedsiębiorczości społecznej i politycznej. Skupia się na badaniach społecznych uwarunkowań postaw przedsiębiorczych, do których zalicza proces socjalizacji, konstrukcji cyklu życia czy statusu, dyskryminacji, wykluczenia, marginalizacji społecznej. Podczas socjalizacji dochodzi do internalizowania norm, wartości, które sprzyjają rozwojowi przedsiębiorczości. Do głównych cech postawy przedsiębiorczej zalicza ona nastawienie na osiagnięcia, wewnątrzsterowność i skłonność do podejmowania ryzyka. Są one zazwyczaj wzmacniane w procesie socjalizacji (Nawojczyk 2009: 89). A. Pocztowski (2004: 233) przyporządkował z kolei cechy osobowościowe do poszczególnych komponentów postawy².

2 Postawa w sensie socjologicznym obejmuje trzy następujące komponenty: poznawczy (cognitive) - wiedza, opinie, poglądy jednostki; emocjonalny (affective) uczucia pozytywne i negatywne, upodobania, uprzedzenia względem przedmiotu postawy, oparte na doświadczeniach jednostki bądź innych; behawioralny (behavioral) - określone reagowanie, zachowanie jednostki względem danego przedmiotu, prowadzące do aktywności, działania (Turowski 2001: 44-55). 
Przykładowymi cechami wpisującymi się w komponent poznawczy są specjalistyczna wiedza, kreatywność, gotowość uczenia się, otwartość czy wrażliwość. Do komponentu emocjonalnego Pocztowski zaliczył np. orientację na przyszłość, niezależność, optymizm, tolerancję dla niejednoznaczności. W komponencie zaś behawioralnym znalazły się m.in. potrzeba osiagnięć, gotowość do podejmowania ryzyka, dynamiczność, innowacyjność, wytrwałość, a także sumienność.

Najczęściej bada się trzy aspekty przedsiębiorczości. Po pierwsze, ujmuje się ją jako postawę określaną w kategoriach indywidualnych cech osobowościowych poszczególnych jednostek. Bada się cechy predestynujące jednostki do bycia osobami przedsiębiorczymi. Po drugie, przedsiębiorczość osadza się w sferze ludzkich działań. Interesujące badawczo wydają się kwestie aktywnego uczestnictwa, doskonalenia własnych umiejętności, inicjatywa w organizowaniu własnego warsztatu pracy oraz wszelka świadomość realizacji zamierzeń wraz z podejmowaniem czynności minimalizowania ryzyka i strat. Trzeci aspekt przedsiębiorczości związany jest z podejmowaniem nowych przedsięwzięć i tworzeniem nowych form organizacyjnych (Chałas 2006: 70).

W literaturze występuje wiele typologii przedsiębiorczości. Jedna z najbardziej znanych i przywoływanych jest klasyfikacja przedsiębiorczości wyróżniona ze względu na rodzaj działań i zachowań przedsiębiorczych autorstwa L. H. Habera (Kapusta 2006: 30-33). Za reprezentatywne wzorce przedsiębiorczości uznaje się tu przedsiębiorczość żywiołowa, ewolucyjną, etyczną, systemową. Przedsiębiorczość żywiołowa jest związana z kreatywnością i innowacyjnością. Od strony pozytywnej przedsiębiorczość wyrażana jest w inicjowaniu i zmienianiu dotychczasowych norm z punktu widzenia nowego ładu ekonomicznego. Od strony zaś negatywnej wskazuje ona na świadome łamanie prawa i zasad społecznych dla osiagnięcia własnych korzyści. Przedsiębiorczość ewolucyjna eksponuje procesowy charakter osobowości jednostki, która podczas podejmowania kolejnych inicjatyw, doskonalenia się, będzie nabywać nowych kompetencji, by zostać osobą przedsiębiorczą. Kolejna odmiana przedsiębiorczości, etyczna, odzwierciedla wewnętrzy system przekonań, norm, wartości w płaszczyźnie religijnej, politycznej oraz społeczno-obyczajowej. Wyrażają się one w religijnym ideale pracy i oszczędności, a także 
bogaceniu się. Przedsiębiorczość systemowa, ostatnia z wyróżnionej powyżej typologii, związana jest z rolą państwa jako promotora w rozwijaniu i kształtowaniu społeczeństwa przedsiębiorczego.

\section{Wieś jako środowisko życia i wychowania młodzieży}

Polska wieś od lat ulega głębokim przeobrażeniom, będącym skutkiem występowania silnych procesów modernizacyjnych. Zmianie podlegają struktury gospodarcze, społeczne, przestrzenne i krajobrazowe. Procesy suburbanizacji doprowadzają do rozmycia granicy między wsią a miastem. Przemiany dokonują się również w samym rolnictwie. Coraz częściej mówi się o obszarach wiejskich jako o wyodrębnionych przez wieś i jej otoczenie pewnych przestrzeniach (Halamska 2011: 236). Krzysztof Gorlach (2004: 157) przedstawił listę najważniejszych procesów, które w największym stopniu oddziałują na obszary wiejskie. Po pierwsze, obserwuje się spadek znaczenia rolnictwa, związany ze zmniejszającą się liczbą osób zatrudnionych w tym dziale gospodarki oraz ze zmianami dotyczącymi produkcji żywności. Po drugie, pojawia się troska o środowisko naturalne i kulturowe, które staje się ważnym graczem w rozgrywkach politycznych. Po trzecie, obszary wiejskie przyciagają nowych użytkowników, niezwiązanych z rolnictwem, ponieważ zaspokajają ich potrzeby i są w stanie sprostać ich wymaganiom. Po czwarte, rodzą się kontrowersje wokół efektów stosowania biotechnologii czy modyfikacji genetycznych. I wreszcie, po piąte, zmiana dotyczy form wspierania rozwoju obszarów wiejskich. Jednakże należy zachować ostrożność w sprowadzaniu suburbanizacji obszarów wiejskich do wzrostu poziomu jakości życia na wsi. Uwagę na ten problem zwraca Krystian Heffner (2011: 48) wskazując na negatywne konsekwencje „umiastowienia” rozwoju społeczno-gospodarczego obszarów wiejskich, przyczyniające się do obniżenia poziomu życia mieszkańców wsi. Należy, według niego, powtórzyć za europejskimi badaczami tezę, że rozwój obszarów wiejskich jest procesem wieloaspektowym, wielopoziomowym, dokonującym się przy udziale licznych aktorów społecznych. Wieloaspektowość dotyczy tu wyjścia poza ujęcie rozwoju 
gospodarczego w rolnictwie i wzięcia pod uwagę wszystkich tych czynników, które przyczyniają się do wzrostu jakości życia na wsi. O wielopoziomowości rozwoju obszarów wiejskich świadczy natomiast fakt przenikania się różnych procesów i elementów zachodzących na różnych poziomach organizacji społeczeństwa $\mathrm{z}$ udziałem wielu aktorów (Gorlach 2004: 158).

Zmiany zachodzą na wsi nie tylko na poziomie makrostrukturalnym, ale również na poziomie mikrostrukturalnym - dotyczą tradycji, obyczajów, a przede wszystkim stylu życia mieszkańców. Wykształciły się specyficzne wzory zachowań, charakterystyczne dla społeczeństwa obywatelskiego. Badania prowadzone przez K. Szafraniec wskazują, że większość mieszkańców badanego obszaru wiejskiego jest zadowolona z miejsca zamieszkania, przy jednoczesnym wskazaniu miasta jako przyszłego miejsca zamieszkania swoich dzieci. Zdecydowana większość ludności deklaruje bezinteresowną pomoc innym ludziom, ale nie ma ona odzwierciedlenia instytucjonalnego, co wyraża się znacznym poziomem nieufności do instytucji formalnych działających w środowisku wiejskim. Również zdecydowana większość osób jest przekonana o tym, że o ile ma wpływ na sprawy swojej gminy, to na problemy powiatu czy województwa już nie (Michalska 2008: 139-140).

Kategorią osób, która szczególnie popiera ideę społeczeństwa obywatelskiego, jest młodzież. Młodych ludzi mieszka na wsi więcej niż w mieście - 21,4\% w wieku 0-17 lat (w mieście 17,2\%) oraz 19,6\% (w mieście 18,5\%) w wieku 18-29 lat (Szafraniec 2011: 363). Grupa ta reprezentuje odmienny styl zaangażowania społecznego, który jest bardziej ufny, otwarty, empatyczny, ujawniający większe pokłady społecznego kapitału. Widoczne jest częstsze i intensywniejsze uczestnictwo młodzieży w działania, w których mamy do czynienia z kapitałem społecznym, czyli w wolontariacie, działaniach dobroczynnych, doświadczeniach w pracy społecznej (Szafraniec 2011: 289-290). Młodzież na wsi jest zarazem w coraz mniejszym stopniu zainteresowana pracą na roli. Są to osoby coraz lepiej wykształcone, co jest wynikiem zmiany kontekstu socjalizacyjnego i edukacyjnego. Jednakże zauważa się tutaj także prawidłowość, iż dzieci z rodzin o wysokim statusie społecznym mają większe szanse na powiększanie zasobów kapitału ludzkiego i społecznego, większe 
szanse edukacyjne. Natomiast szansy tej są pozbawione dzieci z rodzin o niskiej orientacji na edukację i o niskim statusie materialnym. Młodzież wiejska, podobnie jak miejska, wykazuje wysokie aspiracje edukacyjne, jednak wybiera kierunki studiów mniej popularne, takie, na które stosunkowo łatwiej jest się dostać. Po zakończeniu studiów w mieście pozostają młodzi dysponujący wysokimi kompetencjami, rokującymi dobrze na przyszłość. Podkreśla się, że w odróżnieniu od swoich rówieśników miejskich, są to osoby skromniejsze i bardziej przywiązane do wartości tradycyjnych, takich jak rodzina, religia, oszczędność, zaradność i spryt. Młodzież wiejską wyróżnia większe przywiązanie do wartości wykształcenia (Szafraniec 2011: 366-370). Cechy te umożliwiają kreowanie postawy przedsiębiorczej. Warto aktywizować ludzi młodych ze względu na duży potencjał ich energii, zapał, poważne pokłady kreatywności i możliwości szybkiego uczenia się.

\section{Uwarunkowania społeczno-kulturowe}

M. Ruef i M. Lounsbury wyróżnili cztery perspektywy zachowań przedsiębiorczych. W pierwszej z nich, kontekstualnej, na rozwój przedsiębiorczości wpływa środowisko materialne i kulturowe. Druga perspektywa, behawioralna, pozwala na analizę mikrosocjologiczną. Obejmuje ona problemy badawcze charakterystyczne dla społeczno-psychologicznych uwarunkowań przedsiębiorczości, moment w cyklu życia, w którym podejmuje się działalność przedsiębiorczą oraz definiowanie jej zakresu i opartej na niej tożsamości. Analizą zaś wpływu zachowań przedsiębiorczych na powstawanie organizacji, gałęzi przemysłu, zbiorowości i całych społeczeństw zajmuje się perspektywa konstruktywistyczna. Czwarta perspektywa, ekologiczna, bada oddziaływanie środowiska materialnego i kulturowego na rozwój gospodarczy i instytucjonalny, bez uwzględnienia indywidualnych działań przedsiębiorców. Analiza socjologiczna łączy ze sobą spojrzenie indywidualistyczne, psychologiczne z ekonomicznym w kontekście społeczno-kulturowym. Bez znaczenia jest, czy ów kontekst zostaje badany na poziomie mikro czy makro (Nawojczyk 2009: 104-109). 
W literaturze wskazuje się na trzy poziomy uwarunkowań postaw przedsiębiorczych. Po pierwsze, są to cechy osobowościowe, które stanowią ramy uwarunkowań wewnętrznych. Natomiast w skład uwarunkowań zewnętrznych wchodzą warunki makrootoczenia i warunki lokalne. W artykule koncentruję się na prezentacji uwarunkowań społeczno-kulturowych postawy przedsiębiorczej, które wchodzą w zakres uwarunkowań makrootoczenia. Jest to zakres społecznie akceptowanych norm i zachowań, bazujących na społecznych wzorcach i normach postępowania (Chilicka, Citkowski 2005: 17). Do innych uwarunkowań makrootoczenia zalicza się czynniki polityczne, prawne, ekonomiczne czy komunikacyjne - por. rysunek 1 (Lipka 2004: 78).

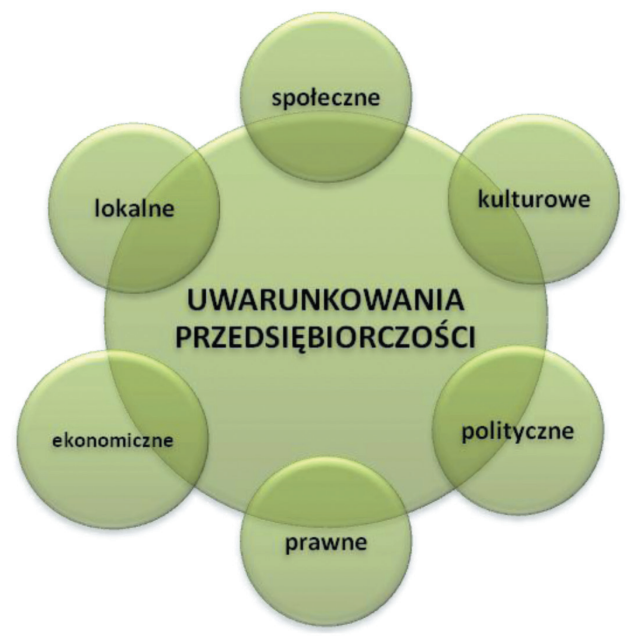

Rysunek 1. Zewnętrzne uwarunkowania przedsiębiorczości Źródło: opracowanie własne

Uwarunkowania kulturowe są ukształtowane przez historyczne formy współżycia społecznego opartego na powszechnie uznawanych wzorach postępowania, normach społecznych. Uwarunkowania społeczne są związane z typem struktury społecznej, stratyfikacji społecznej. Zachowania przedsiębiorcze są wynikiem integracji 
i trwałości struktury społecznej (Piecuch 2013: 83). Uwarunkowania społeczno-kulturowe, wchodzące w zakres czynników makrootoczenia, występują w bliskim otoczeniu człowieka. Środowisko bowiem, z którego wywodzi się człowiek, znacząco wpływa na ukształtowanie jego osobowości, jego działań i dalszego życia. Literatura poświęcona problematyce przedsiębiorczości podkreśla znaczącą rolę czynników kulturowych i społecznych, obok ekonomicznych, w kształtowaniu postawy przedsiębiorczej. Uwagę na ten fakt zwracał już P. F. Drucker, który wskazywał, że wydarzenia ekonomiczne nie są jedynymi czynnikami otaczającymi człowieka przedsiębiorczego. Podobnego zdania jest M. Bratnicki, dla którego przedsiębiorczość jest również złożonym procesem społecznym. Dla D. Lavoi z kolei przedsiębiorczość to interpretowanie kultury oraz wpływanie na nią. Według niego przedsiębiorczość jest zakorzeniona w kulturze i znacząco przez nią kształtowana. T. Kraśnicka do czynników społeczno-kulturowych zalicza system wartości i przekonań, norm moralnych, tradycje przedsiębiorczości na danym terytorium, model rodziny i więzi rodzinnych oraz klimat społeczny. W wielu społeczeństwach znaczącą rolę odgrywa system moralny, religijny. W kulturach religijnych przywiązuje się wagę do takich cech osobowościowych, jak pracowitość, uczciwość, posłuszeństwo, lojalność, przywiązanie do tradycji (Piecuch 2013: 109-110). M. Weber reprezentował nurt myślenia łączący rozwój ekonomiczny z wartościami religijnymi (zob. Weber 1994). B. Hryń zaś (2003: 167) do uwarunkowań społeczno-kulturowych zalicza system wartości i przekonań, tradycje przedsiębiorczości, nastroje społeczne, model rodziny i więzi rodzinne, kwalifikacje i wiedzę, zaufanie jako zasób kulturowy.

Podsumowując, uwarunkowania społeczno-kulturowe odgrywają bardzo ważną rolę $\mathrm{w}$ procesie kształtowania postawy przedsiębiorczej osoby, która jest osadzona w pewnych realiach życia społecznego, wychowana w danej rodzinie, z określonymi wzorcami zachowań, sposobami myślenia oraz cechami osobowościowymi. Poniżej zostaną szerzej omówione uwarunkowania społeczno-kulturowe - takie jak rodzina, edukacja, kultura. 


\section{Rodzina}

Coraz częściej wskazuje się, że środowisko rodzinne może sprzyjać lub ograniczać kształtowanie cech przedsiębiorczych. Dominujący system wartości w rodzinie, potem w szkole, może rozwijać postawę przedsiębiorczą od najmłodszych lat (Bieniok 2007: 226). Rodzina pełni wiele funkcji, wśród których najważniejsza jest socjalizacja. W rodzinie po raz pierwszy dziecko zapoznaje się z kulturowym dziedzictwem społeczeństwa: językiem, wartościami, normami, obyczajami oraz standardami moralnymi (Szlendak 2010: 116). Socjalizacja umożliwia nabycie określonych kompetencji i umiejętności, będących podstawą interakcji międzyludzkich opartych na systemie wartości i norm społecznie akceptowanych, które ukierunkowuja popędy i potrzeby ludzkie. Człowiek nabywa również sprawności fizycznej i umiejętności posługiwania się różnymi przedmiotami. Dzięki przyswojeniu języka i symbolów kultury, a także ekspresji emocji poznaje sposoby nawiązywania i podtrzymywania komunikacji z innymi ludźmi. Socjalizacja pozwala również na wyrażanie swoich emocji i konceptualne pojmowanie rzeczywistości. Jednostka internalizuje wartości, normy, wzorce, aspiracje, cele i działania, do których dążą członkowie społeczeństwa (Jasińska-Kania 1991: 91).

Rodzina stanowi więc pierwszą instytucję społeczną ${ }^{3}$, w której dokonuje się proces socjalizacji. Odbywa się on dwiema drogami. Pierwsza to wychowanie, dzięki któremu następuje internalizacja społecznie akceptowanych norm i wartości. Drugi mechanizm to kontrola społeczna służąca do wykształcenia dyscypliny i posłuszeństwa. Zarówno wychowanie, jak i kontrola społeczna przygotowują młodego człowieka do stania się pełnoprawnym uczestnikiem życia społecznego. Rodzina służy wykształceniu natury społecznej dziecka, humanizowaniu jego popędów oraz pomaga mu przy osiaganiu celów. Dzięki odpowiednim zabiegom wychowawczym spełnia funkcje społeczne w określonym

${ }^{3}$ Instytucję społeczną rozumie się tutaj w sensie socjologicznym, jako: ,element struktury społecznej organizujący podstawowe działania i czynności oraz zaspokajający potrzeby społeczne" (Marshall 2008: 126). 
czasie, miejscu oraz warunkach społecznych, kulturowych, ekonomicznych i etycznych (Jacher 2001: 20-21). To, jak zostaną wychowane dzieci, w głównej mierze zależy od wykształcenia rodziców i ich świadomości pedagogicznej. Według A. Gizy-Poleszczuk rodzina wyposaża młodego człowieka przede wszystkim w kapitał ludzki. Są to inwestycje nadawane w okresie dzieciństwa, jak kondycja fizyczna i psychiczna, kapitał kulturowy, wykształcenie, umiejętności, oraz w okresie młodości - udostępnianie szans, minimalizowanie ryzyka podejmowanych działań (Giza-Poleszczuk, Marody, Rychard 2000: 109-110).

Rodzina odgrywa zatem znaczącą rolę w kształtowaniu postaw przedsiębiorczych. Podkreśla się, że w środowisku rodzinnym istotne znaczenie ma świadomość ekonomiczna, przedsiębiorcza posiadana przez rodziców. Socjalizacja ekonomiczna jest ważną częścią procesu społecznego i poznawczego rozwoju człowieka. Jest związana z rozumieniem świata ekonomicznego i włączaniem do niego swoich samodzielnych działań ekonomicznych. Jednostka poznaje ten świat, testuje teorie odnoszące się do niego, sprawdza je w ramach własnych doświadczeń i praktyk. Podobnie jak w socjalizacji ogólnej, wymagane są tutaj interakcje ze światem społecznym. O sukcesie przebiegu socjalizacji ekonomicznej decydują warunki środowiska rodzinnego, przynależność do klasy społecznej. Źródłem wiedzy ekonomicznej są szkoła, media, rodzice i inne osoby. Kluczowym momentem socjalizacji ekonomicznej jest rozumienie i poznawanie wartości pieniądza. Przyszła aktywność ekonomiczna dziecka kształtuje się przez poznanie znaczenia ekonomicznej wymiany pieniądza oraz zwyczajów dotyczących użycia pieniądza, takich jak oszczędzanie, wydawanie, dawanie, udział w grach hazardowych. Wiedza ta w znacznym stopniu jest determinowana doświadczeniem i przynależnością do klasy społecznej oraz działaniami wychowawczymi. Kolejnym, ważnym momentem w socjalizacji ekonomicznej jest pojęcie własności. Istotne jest rozróżnienie między posiadaniem danego przedmiotu a byciem jego właścicielem. Umiejętność zrozumienia istoty transakcji jest procesem długotrwałym i stopniowym. Jednakże słowem, które zawładnęło - przede wszystkim - ekonomicznymi definicjami przedsiębiorczości oraz które stanowi klucz do zrozumienia ekonomii, jest zysk. Zrozumienie, czym jest zysk, następuje 
podczas dokonywania samodzielnych zakupów oraz obserwowania decyzji ekonomicznych podejmowanych przez rodziców (Bromboszcz 1995: 62-69). Badania pokazuja, że część społeczeństwa nie ma w pełni wykształconej świadomości ekonomicznej, nie jest ukierunkowana na osiaganie zysku, sukcesu, nie jest otwarta na nowe doświadczenia, nie ma poczucia własnej skuteczności i elastyczności (Cierniak-Szóstak, Karwińska 2007: 212-213).

Postawa przedsiębiorcza dostarcza wielu możliwości na drodze życiowej, pozwala osiagnąć sukces i zysk. Otwiera wiele dróg do społecznego uczestnictwa oraz pozwala na lepsze dostosowywanie się do zaistniałych warunków społeczno-ekonomicznych. Według P. Wachowiaka ważne jest wykształcenie u dziecka kilku kluczowych umiejętności w socjalizacji przedsiębiorczej. Po pierwsze, należy ukształtować w dziecku akceptację samego siebie. Jest to możliwe dzięki poznaniu swoich mocnych oraz słabych stron. Pozwala to bowiem na stawianie sobie realnych celów oraz podejmowanie racjonalnych decyzji i działań zgodnych z własnymi możliwościami. Rodzice powinni ukierunkowywać dziecko na wzmacnianie swoich mocnych stron oraz na zwalczanie słabych. Po drugie, człowiek powinien umieć wykazywać się swoimi sukcesami, ponieważ to one mobilizuja go do dalszego działania. Kolejnym ważnym elementem socjalizacji przedsiębiorczej powinno być towarzyszące wszelkim działaniom pozytywne myślenie. Ono stanowi podwaliny pewności siebie i pozwala podjąć decyzje bądź zainicjować określone działania. Kluczowym zaś czynnikiem sukcesu jest trudne do wykształcenia kreatywne myślenie. Kreatywność to twórcze nastawienie do rozwiązywania problemów, pokonywania przeszkód oraz wykorzystania niezbędnych informacji. Kreatywności towarzyszy optymizm, pomysłowość, otwartość na wszelkie możliwości oraz wytrwałość w dążeniu do postawionych sobie celów (Wachowiak 2007: 146-148).

S. Kawula twierdzi, że istnieją znaczące różnice w świadomości pedagogicznej rodziców miejskich i wiejskich. Jest to wynikiem nie tylko słabszego wykształcenia ludności wiejskiej, ale i ogólnego poziomu kultury oraz gorszego przygotowania pedagogicznego. Na aspiracje dzieci mniejszy wpływ ma środowisko, w którym mieszkaja, wychowują się, niż ich pochodzenie społeczne. Dzieci pochodzące z rodzin 
o wysokim statusie społecznym wybierają zawody bardziej prestiżowe (Papież 2006: 314-318).

Badania wykazują, że większość młodzieży wiejskiej zamierza po gimnazjum kontynuować edukację. Jedną z podstawowych determinant planów edukacyjnych tej młodzieży jest status społeczny rodziny pochodzenia. Jest to ważny aspekt, gdyż pokolenie dzieci może przejawiać, wyznawać te same wartości, orientacje, wzory co ich rodzice. Docenianie przez nich roli edukacji może być odbiciem cennych wartości, wpojonych im przez rodziców, dziedziczenia kapitału społeczno-kulturowego. Im wyższy status społeczny rodziny pochodzenia, tym częściej młodzież aspiruje do najwyższych pozycji społecznych i tym rzadziej dąży do zajęcia średnich i niskich miejsc w strukturze społecznej (Domalewski 2006b: 250). Duże znaczenie mają również kariery edukacyjne rodzeństwa. Potwierdza się, że w rodzinie o niskim statusie społecznym nastolatek będzie miał wysokie aspiracje edukacyjne, o ile taką drogę obrało starsze rodzeństwo. Zatem plany edukacyjne młodzieży są zdeterminowane z jednej strony przez status społeczny rodziny, a z drugiej przez doświadczenia edukacyjne starszego rodzeństwa (Domalewski 2006a: 243). Może wystapić zatem dziedziczenie „negatywnego” kapitału, przejawiającego się w niskich aspiracjach edukacyjnych, bądź „pozytywnego” kapitału, gdy występują wysokie aspiracje edukacyjne. Z rodziny o „negatywnym” kapitale wywodzą się tzw. early school-leavers - opuszczający szkołę z bardzo niskimi kwalifikacjami, nie podejmujący żadnych działań w kierunku podnoszenia swoich kwalifikacji i wiedzy (Bojar 2013: 230-237).

Rodzina odgrywa istotną rolę w zachęcaniu i tworzeniu dzieciom warunków do edukowania czy też uczestnictwa w innych aktywnościach, które rozwijają ich kompetencje społeczne, przedsiębiorcze, intelektualne. Większe zorientowanie na edukację występuje w rodzinach silnie zorientowanych na wykształcenie i sukces edukacyjny dzieci. Kapitał społeczno-kulturowy przeważa nad kapitałem ekonomicznym w procesie socjalizacji jednostki. Podejmując badania na temat przedsiębiorczych postaw młodzieży wiejskiej należy więc uwzględniać sytuację społeczno-kulturową środowiska rodzinnego. Ważnym czynnikiem korygującym wpływ rodziny na cechy przedsiębiorcze jednostki moga 
być instytucje edukacyjne. Na każdym etapie edukacji rola szkoły (podstawowej, gimnazjalnej, wyższej) w rozwijaniu m.in. postaw przedsiębiorczych może być nader istotna.

\section{Edukacja}

Szkoła jest taką instytucją społeczną, która dostarcza wiedzy pozwalającej zrozumieć różne zjawiska społeczne, polityczne, ekonomiczne i kształtować krytyczne myślenie, pomagać uczniom budować poczucie własnej wartości, przygotowywać ich do podejmowania ważnych działań i uczyć odpowiedzialności oraz troski o dobro wspólne (Baran, Koczerba 2006: 135). Szkoła odgrywa zatem znaczącą rolę w rozwijaniu postawy przedsiębiorczej. W zakresie przedmiotu nauczania wszystkie przedmioty szkolne dostarczają treści merytorycznych dotyczących przedsiębiorczości. Celem jest rozwijanie aspiracji, planów życiowych nawiązujących do rynku pracy czy możliwości założenia własnej firmy. Ważne jest rozpoznanie predyspozycji ucznia i stworzenie mu (na lekcji bądź w kołach) możliwości rozwijania jego zainteresowań (Zioło 2012: 15).

W tym kontekście dostrzega się znaczące różnice między miastem a wsią, co wskazuje na marginalizację młodzieży z obszarów wiejskich. Nierówności te zaczynają się już na poziomie edukacji przedszkolnej. Dostęp do edukacji przedszkolnej dzieci wiejskich jest realnie mniejszy niż dzieci miejskich, co wpływa na możliwości upowszechniania edukacji w obu tych środowiskach. Dzieci wiejskie rzadziej mogą korzystać z przedszkoli, gdyż tych jest niewiele. Na niektórych obszarach wiejskich takich placówek w ogóle nie ma. Dzieci częściej są więc zdane na oddziały przedszkolne. Mniej jest również na wsi szkół podstawowych. Obserwuje się duże dysproporcje w uczestnictwie uczniów wiejskich i miejskich w zajęciach pozaszkolnych czy pozalekcyjnych. Oferta zajęć pozalekcyjny na wsi jest uboższa - rodzice mieszkający na wsi znacznie rzadziej deklarują aktywność swoich dzieci w takich formach edukacyjnych. Edukacja nieformalna dodatkowo pogłębia nierówności edukacyjne dzieci wiejskich i miejskich. Wskazuje się również, że szkoły podstawowe na wsi są dużo mniejsze. $Z$ jednej strony sprzyja to 
kameralności zajęć i większej dyscyplinie, ale z drugiej strony szkoły te są niedoinwestowane oraz mają ubogą infrastrukture, co wyraża się w braku sal gimnastycznych, świetlic, czytelni, stołówek czy sal komputerowych. Również niższy odsetek nauczycieli wiejskich charakteryzuje się wykształceniem wyższym. W przypadku gimnazjów usytuowanych na wsi różnica infrastrukturalna jest mniejsza. Gimnazja wiejskie pod względem wyposażenia, oferty zajęć pozalekcyjnych i wykształcenia nauczycieli niewiele odbiegają od szkół miejskich, co jednakże odbyło się kosztem szkół podstawowych. Występują przy tym różnice w wynikach egzaminów gimnazjalnych młodzieży szkół wiejskich i miejskich oraz wielkomiejskich, które zmniejszają się tylko nieznacznie (Dolata 2008: 82-94).

W obliczu globalizacji, ewolucji gospodarki opartej nie tylko na wiedzy, ale i na zrównoważonym rozwoju, kapitał ludzki ulega jakościowemu przeobrażaniu. Zmiany w sposobie wytwórczości, produkcji i w zatrudnieniu oraz wkraczanie w życie nowoczesnych technologii wymagają nabycia nowych umiejętności, kompetencji kluczowych, skoncentrowanych na wyżej wymienionych elementach procesu globalizacji (Janc 2004: 77). Wraz z przemianami reguł kształtowania się kapitału ludzkiego zmieniają się również oczekiwania przedsiębiorców co do kompetencji poszukiwanych absolwentów. Na kompetencje człowieka składają się wiedza (wiedza deklaratywna), umiejętności (wiedza proceduralna) i postawy (Sidor-Rządkowska 2006: 21). W większości państw europejskich wdrażana jest koncepcja uczenia się przez całe życia (lifelong learninig), która obejmuje proces uczenia się od przedszkola do wieku emerytalnego, włączając w to system nauki formalnej (szkoły, inne placówki systemu edukacji), pozaformalnej (w instytucjach poza systemem edukacji) i nieformalnej (naturalnej). Efektem uczenia się przez całe życie jest poszerzanie wiedzy, udoskonalanie umiejętności, kompetencji - osobistych, społecznych i zawodowych (Błędowski, Nowakowska 2010: 18). Kontynuację edukacji po szkole ponadgimnazjalnej stanowi podjęcie nauki na uczelni wyższej. Obecnie główną barierą podjęcia nauki na studiach wyższych przez młodzież wiejską jest miejsce zamieszkania. Sprawia to, że młodzież z obszarów wiejskich ma mniejsze szanse na uzyskanie wykształcenia wyższego niż młodzież 
miejska. Zauważa się, że im bardziej zurbanizowany jest obszar, tym wyższe wykształcenie mająjego mieszkańcy. Młodzież wiejska częściej wybiera uczelnie zlokalizowane w mniejszych ośrodkach miejskich, czyli o mniejszym prestiżu i gorszej jakości kształcenia. W wyborach młodzieży wiejskiej przeważają szkoły niepubliczne oraz tradycyjne kierunki studiów. Natomiast młodzi z miast wybierają częściej uczelnie publiczne oraz ,przyszłościowe” i ,modne” kierunki. Jak wskazują wyniki badań prowadzonych przez pracowników Uniwersytetu Mikołaja Kopernika w Toruniu, młodzież z obszarów wiejskich wybierała kierunki na wydziałach (w kolejności malejącej): Teologicznym, Chemii, Biologii i Nauk o Ziemi, Matematyki i Informatyki, Fizyki, Astronomii i Informatyki Stosowanej, Filologicznym, Historycznym, Humanistycznym, Nauk Ekonomicznych i Zarządzania, Sztuk Pięknych. Zdecydowanie dominuje kierunek teologiczny, gdzie najczęściej jest wybierana specjalność kapłańska. Ponadto, wśród kierunków popularnością cieszą się: filologia polska, romańska, rosyjska, socjologia, matematyka, oraz chemia. Kierunki te są najczęściej wybierane przez młodzież z obszarów wiejskich z kilku powodów. Po pierwsze, występuje tutaj niski poziom trudności przejścia przez proces rekrutacji. Jest on związany po części $\mathrm{z}$ autoselekcją, gdyż w mniemaniu owej grupy młodzieży kierunki te są „łatwiejsze”. Po drugie, jest to też związane z dwustopniową organizacją studiów. Mianowicie, każdy z tych kierunków można zakończyć na etapie licencjatu i legitymować się wtedy posiadaniem wykształcenia wyższego. Po trzecie, wybór takich, a nie innych kierunków studiów jest uzależniony od postrzegania studiów jako ścieżki zdobycia tradycyjnego zawodu, jakim jest np. zawód nauczyciela - stąd wybór pada na filologię, chemię lub matematykę. Po czwarte, co zostało już wyżej wspomniane, wybierane są te kierunki, które są mało prestiżowe i wręcz deficytowe, na których najczęściej występuje drugi nabór (Domalewski, Wasielewski 2005: 359-365).

W przypadku młodzieży wiejskiej głównym motywatorem do kształcenia, rozwijania swoich kompetencji, podnoszenia swojego wykształcenia jest chęć osiagnięcia wyższej pozycji społecznej (Wasielewski 2006: 333). Ważną barierę stanowi tutaj miejsce zamieszkania - wieś. Tym samym jest ona postrzegana jako miejsce nieatrakcyjne 
dla rozwoju przedsiębiorczości i zdobywania wykształcenia, uzyskania dobrej pracy. Młodzi tych wartości poszukują w mieście.

\section{Kultura}

Beata Glinka do kulturowych uwarunkowań przedsiębiorczości zalicza:

zespół wartości, norm postępowania i wzorów zachowań charakterystyczny dla danej społeczności, który znajduje odzwierciedlenie w wyobrażeniach o gospodarce i interpretacjach zjawisk w niej zachodzących, regulując równocześnie formę i skalę działań przedsiębiorczych podejmowanych przez członków społeczności (Glinka 2008: 59).

Dokonany przez Glinkę przegląd literaturowy pozwolił na wyróżnienie kilku związków między kulturą a przedsiębiorczością. Próbuje ona odpowiadać na następujące pytania: Jaka jest relacja między kulturą a innymi zmiennymi kształtującymi działania przedsiębiorcze? Czy istnieją uniwersalne wartości, które można zaadaptować w różnych krajach? Jaką rolę odgrywają kapitał społeczny i zaufanie społeczne w działaniach osób przedsiębiorczych? Jaki jest wpływ społecznego postrzegania i aktywności osób na ich działania przedsiębiorcze? Jakie wartości kulturowe wyznają osoby przedsiębiorcze i jakie są ich postawy wobec pracy? (Glinka 2008: 69).

Kultura wywiera duży wpływ na ludzkie zachowania oraz myślenie. Dostarcza na co dzień wiele wzorców, przekonań, celów i schematów (Rollnik-Sadowska 2010: 41). Trudno jest jednoznacznie odpowiedzieć, jakie wzorce kulturowe dominują w danym społeczeństwie, na kulturę każdego społeczeństwa ma bowiem wpływ przede wszystkim historia kraju i jego tradycja. W polskiej kulturze zauważa się wartości, które raczej nie sprzyjają rozwojowi postawy przedsiębiorczej. Wskazuje się na brak poszanowania dla procesu bogacenia się, wyrażający się w podejrzliwości w stosunku do dorobku osób, które wzbogaciły się. Ponadto zauważalny jest dysonans między pracą a bogactwem. Praca jest wartością cenioną, ale rzadko jest wiązana $z$ bogactwem. Nie zawsze prowadzi do polepszenia poziomu życia. Poza tym niektórzy 
podchodzą do pracy w sposób odtwórczy, nie zaś kreatywny, twórczy. Stosunek do poszanowania prawa jest niejednoznaczny, ciagle istnieje „ciche” przyzwolenie na jego łamanie lub naginanie. Sama przedsiębiorczość i prowadzenie działalności gospodarczej jest postrzegana raczej negatywnie i otoczona negatywnymi stereotypami. Taki negatywny stosunek do przedsiębiorczości został ukształtowany przez długotrwałe tradycje historyczne oraz poprzez codzienne doświadczenia i praktyki Polaków. Ważną rolę w postrzeganiu przedsiębiorczości odegrały też liczne nieprawidłowości w procesie przekształceń własnościowych. Takie wartości i wyobrażenia mają swoje źródła w niskim zaufaniu społecznym, które jest jednym z istotnych problemów współczesnych kulturowych uwarunkowań w Polsce. Zaufanie dodaje odwagi, skłania do aktywności i przedsiębiorczości (Glinka 2008: 185-187). Jak pokazują najnowsze wyniki badania przeprowadzonego przez Centrum Badania Opinii Społecznej, Polacy cechują się wysokim poziomem zaufania do rodziny $(97 \%)$, znajomych $(91 \%)$ oraz dalekich krewnych $(87 \%)$. Ten zadowalający poziom zaufania w sferze prywatnej nie znajduje jednak odbicia w sferze publicznej. Tylko 35\% osób ufa bowiem nieznajomym (Boguszewski 2014). Przyczyn tak niskiego poziomu zaufania można się doszukiwać głównie w spuściźnie okresu transformacji. Ciagłe żywy jest podział „my-oni”, co zdają się pogłębiać działania współczesnych polityków (zob. Przyłęcki 2012). Rozczarowanie, rzesza „,przegranych”, doświadczenia wczesnego okresu transformacji oraz niskie zaufanie do prawa i wymiaru sprawiedliwości również przyczyniły się do braku zaufania wśród społeczeństwa (Glinka 2008: 186-187).

Postrzeganie przedsiębiorczości ulega jednak powolnej zmianie. Obecnie jest ona kojarzona z pracowitością i zaradnością, a także z ciężką pracą i specyficznymi cechami charakteru. Rozwój przedsiębiorczości w opinii wielu osób sprzyja powstawaniu nowych miejsc pracy (Rollnik-Sadowska 2010: 42).

Poznanie kulturowych mechanizmów warunkujących przedsiębiorczość pozwala na lepsze i głębsze zrozumienie stosunku do przedsiębiorczości i możliwości jej rozwoju. Stosunek młodzieży do podstawowych wartości i norm związanych z aktywnością, w tym zawodową, jest jedną z determinant rozwijających jej postawy przedsiębiorcze. 


\section{Podsumowanie}

Czynniki społeczno-kulturowe w znacznym stopniu mogą sprzyjać bądź stanowić barierę w rozwoju postaw przedsiębiorczych młodzieży. Analizie teoretycznej poddane zostały trzy czynniki społeczno-kulturowe: rodzina, edukacja, kultura. Wskazuje się, że pomimo dużego potencjału drzemiącego w młodzieży wiejskiej napotyka ona wiele trudności w kontekście rozwoju postawy przedsiębiorczej. W przypadku młodzieży wiejskiej wciąż występuje niższy poziom edukacji, niska samoocena, negatywne stereotypy dotyczące postrzegania obszarów wiejskich oraz mniejsze szanse rozwoju. Głównymi źródłami takiego stanu rzeczy są przede wszystkim pochodzenie społeczne, niska świadomość ekonomiczna rodziców, którą mogli przekazać w procesie socjalizacji, niskie wykształcenie i ogólne niedoinformowanie ludności wiejskiej, a także niedoskonałości systemu edukacyjnego, który powinien wyrównywać szanse i uzupełniać braki wiedzy oraz umiejętności. Jednakże warto zwrócić uwagę na rosnącą wartość autoteliczną edukacji i pracy, zwłaszcza w aspekcie zakładania własnej działalności gospodarczej, a także wysokie zaangażowanie społeczne tej kategorii młodzieży. Taka postawa i nastawienie na rozwój mogą być wynikiem ogólnego zrewaloryzowania zasobów w sferze wartości. Wzrosło bowiem znaczenie wiedzy, przedsiębiorczości, innowacyjności, kreatywności, które są postrzegane jako istotny czynnik rozwoju lokalnego, regionalnego i krajowego. Szczególnie pożądana jest przedsiębiorczość wiejska w działalności rolniczej oraz pozarolniczej, zgodnie z polityką wielofunkcyjnego rozwoju wsi, to od osób przedsiębiorczych bowiem, ich aktywności, dynamiki i zaangażowania zależy rozwój wsi. Kształtowanie zatem postaw przedsiębiorczych młodzieży, inicjujących określone działania i zachowania na rzecz rozwoju lokalnego, jest ważnym przedsięwzięciem. Braki socjalizacyjne czy edukacyjne powinny być niwelowane poprzez organizowanie różnego rodzaju szkoleń, programów edukacyjnych, specjalnych kół, inkubatorów przedsiębiorczości w zakresie kształtowań pożądanych cech osobowościowych, jak i w zakresie realnej pomocy przy zakładaniu działalności gospodarczej i wszelkiej innej aktywności 
społeczno-obywatelskiej. Te działania powinny być realizowane przez wyspecjalizowane w tym zakresie instytucje i organizacje lokalne we współpracy z władzą lokalną.

\section{Bibliografia}

Baran E., Koczerba A., 2006, Spoleczeństwo obywatelskie a aktywność obywatelska młodzieży. Omówienie wybranych inicjatyw i działań, [w:] M. S. Szczepański, A. Śliz (red.), Kapitaty: ludzie i instytucje. Studia i szkice socjologiczne, Śląskie Wydawnictwa Naukowe, Tychy-Opole

Bieniok H., 2007, Ksztaltowanie postaw przedsiębiorczych młodzieży w rodzinie, szkole i uczelni, [w:] P. Wachowiak, M. Dąbrowski, B. Majewski (red.), Ksztattowanie postaw przedsiębiorczych a edukacja ekonomiczna, Wydawnictwo Akademii Ekonomicznej, Warszawa

Bławat F., 2003, Przedsiębiorca $w$ teorii przedsiębiorczości i praktyce malych firm, Gdańskie Towarzystwo Naukowe, Gdańsk

Błędowski P., Nowakowska M., 2010, Podstawy ksztatcenia ustawicznego, Wydawnictwo ego, Łódź

Boguszewski R., 2014, Zaufanie w relacjach międzyludzkich, Komunikat CBOS, nr 29, Warszawa

Bojar H., 2013, Rodzina w małym mieście, Wydawnictwo IFiS PAN, Warszawa

Bromboszcz E., 1995, Socjalizacja ekonomiczna - nowy kierunek socjalizacji, [w:] E. Mandal, R. Stefańska-Klar (red.), Wspótczesne problemy socjalizacji, Wydawnictwo Uniwersytetu Śląskiego, Katowice

Chałas K., 2006, Godność człowieka punktem wyjścia i dojścia do przedsiębiorczości, [w:] K. Jaremczuk (red.), Uwarunkowania przedsiębiorczości - aspekty ekonomiczne $i$ antropologiczno-spoteczne, Wydawnictwo PWSZ, Tarnobrzeg

Chilicka E., Citkowski M., 2005, Istota i czynniki przedsiębiorczości, [w:] B. Plawgo (red.), Lokalne uwarunkowania rozwoju przedsiębiorczości, Wydawnictwo Państwowej Wyższej Szkoły Informatyki i Przedsiębiorczości, Łomża

Cierniak-Szóstak E., Karwińska A., 2007, Socjalizacja do przedsiębiorczości. Możliwości i ograniczenia, [w:] P. Wachowiak, M. Dąbrowski, B. Majewski (red.), Ksztaltowanie postaw przedsiębiorczych a edukacja ekonomiczna, Wydawnictwo Akademii Ekonomicznej, Warszawa

Dolata R., 2008, Szkoła - segregacje - nierówności, Wydawnictwa Uniwersytetu Warszawskiego, Warszawa

Domalewski J., 2006a, Plany edukacyjne wiejskiej młodzieży: między sfera ,,możliwego" $i$, niemożliwego", [w:] K. Szafraniec (red.), Jednostkowe i spoleczne zasoby wsi, Instytut Rozwoju Wsi i Rolnictwa Polskiej Akademii Nauk, Warszawa 
Domalewski J., 2006b, Reforma edukacji - szkoła wiejska - środowisko lokalne. Wzajemne uwarunkowania i zależności, [w:] K. Szafraniec (red.), Kapitat ludzki i zasoby społeczne wsi, Instytut Rozwoju Wsi i Rolnictwa Polskiej Akademii Nauk, Warszawa

Domalewski J., Wasielewski K., 2005, Dostęp młodzieży wiejskiej do edukacji - z perspektywy zmian w szkolnictwie średnim i wyższym, [w:] A. Rosner (red.), Uwarunkowania i kierunki przemian społeczno-gospodarczych na obszarach wiejskich, PAN, Warszawa

Drucker P. F., 2004, Natchnienie i fart, czyli innowacja i przedsiębiorczość, „Studio Emka", Warszawa

Duraj J., Papiernik-Wojdera M., 2010, Przedsiębiorczość i innowacyjność, Difin, Warszawa Gabińska C., 2012, Ksztatcenie na rzecz przedsiębiorczości na obszarach wiejskich, [w:] Rola przedsiębiorczości w edukacji, ser. Przedsiębiorczość - Edukacja, nr 8, red. Z. Zioło, T. Rachwał, Zakład Przedsiębiorczości i Gospodarki Przestrzennej Instytutu Geografii Uniwersytetu Pedagogicznego w Krakowie, Wydawnictwo Nowa Era, Warszawa-Kraków: 259-277

Gaweł A., 2007, Ekonomiczne determinanty przedsiębiorczości, Wydawnictwo Uniwersytetu Ekonomicznego, Poznań

Giza-Poleszczuk A., Marody M., Rychard A., 2000, Strategie i system. Polacy w obliczu zmiany społecznej, Wyd. IFiS PAN, Warszawa

Glinka B., 2008, Kulturowe uwarunkowania przedsiębiorczości w Polsce, Polskie Wydawnictwo Ekonomiczne, Warszawa

Glinka B., Gudkova S., 2011, Przedsiębiorczość, Oficyna, Warszawa

Gorlach K., 2004, Socjologia obszarów wiejskich, Wydawnictwo Naukowe Scholar, Warszawa

Grzegorzewska-Mishka E., 2010, Współczesne uwarunkowania rozwoju przedsiębiorczości w Polsce, Oficyna Wydawnicza, Warszawa

Halamska M., 2011, Wieś jako przedmiot badań naukowych, [w:] M. Halamska (red.), Wieś jako przedmiot badań na poczatku XXI wieku, Wydawnictwo Naukowe Scholar, Warszawa

Heffner K., 2011, Wieś jako przedmiot badań w gospodarce przestrzennej. Procesy zagospodarowania przestrzeni wiejskiej w Polsce., [w:] M. Halamska (red.), Wieś jako przedmiot badań na poczqtku XXI wieku, Wydawnictwo Naukowe Scholar, Warszawa

Hryń B., 2003, Społeczno-kulturowe uwarunkowania przedsiębiorczości, [w:] K. Jaremczuk (red.), Uwarunkowania rozwoju przedsiębiorczości - szanse i zagrożenia, Państwowa Wyższa Szkoła Zawodowe im. prof. S. Tarnowskiego w Tarnobrzegu, Tarnobrzeg

Jacher W., 2001, Socjalizacja w rodzinie, [w:] H. Cudak (red.), Socjalizacja i wychowanie we współczesnych rodzinach polskich, Naukowe Wydawnictwo Piotrkowskie przy Filii Akademii Świętokrzyskiej, Piotrków Trybunalski 
Jamka B., 2012, Potencjał ludzki w rozwoju przedsiębiorczości indywidualnej i korporacyjnej, Difin, Warszawa

Janc K., 2004, Znaczenie kapitalu ludzkiego w procesach globalizacji, [w:] G. Rdzanek, E. Stadtmüller, Człowiek, region, państwo w procesach globalizacji, regionalizacji oraz integracji, Uniwersytet Wrocławski, Wrocław

Jasińska-Kania A., 1991, Socjologiczna koncepcja osobowości, [w:] W. Morawski, Z. Krawczyk (red.), Socjologia. Problemy podstawowe, PWN, Warszawa

Kapusta F., 2006, Przedsiębiorczość. Teoria i praktyka, Wyższa Szkoła Zarządzania i Bankowości, Poznan-Wrocław

Lipka A., 2004, Strategiczne i kulturowe uwarunkowania przedsiębiorczości pracowników, [w:] M. Juchnowicz (red.), Kapital ludzki a kształtowanie przedsiębiorczości, Wydawnictwo Poltext, Warszawa

Marshall G. (red.), 2008, Stownik socjologii i nauk spolecznych, Wydawnictwo Naukowe PWN, Warszawa

Michalska S., 2008, Aktywność społeczna i postawy obywatelskie mieszkańców wsi a rodzaje ich życiowych orientacji, [w:] P. Ruszkowski, H. Podedworna (red.), Spoteczne aspekty zrównoważonego rozwoju wsi w Polsce, Wydawnictwo Naukowe Scholar, Warszawa

Milian L., 2000, Przedsiębiorczość i przedsiębiorstwo turystyczne. Socjologiczne uwarunkowania sukcesu, Wydawnictwo PC, Częstochowa

Nawojczyk M., 2009, Przedsiębiorczość. O trudnościach w aplikacji teorii, Nomos, Kraków

Papież J., 2006, Przemiany warunków socjalizacyjno-edukacyjnych na wsi, Oficyna Wydawnicza „Impuls”, Kraków

Piecuch T., 2013, Przedsiębiorczość. Podstawy teoretyczne, Wydawnictwo C. H. Beck. Warszawa

Pocztowski A., 2004, Narzędzia zarzqdzania kapitałem ludzkim kreujące postawy przedsiębiorcze, [w:] M. Juchnowicz (red.), Kapital ludzki a ksztaltowanie przedsiębiorczości, Wydawnictwo Poltext, Warszawa

Przyłęcki P., 2012, Populizm w polskiej polityce. Analiza dyskursu, Wydawnictwo Sejmowe, Warszawa

Ratajczak Z., 2012, Przedsiębiorczość. Źródta i uwarunkowania psychologiczne, Difin, Warszawa

Rek M., Woźniak W., 2005, Wyrównywanie szans? Reforma polskiego systemu edukacji a realizacja idei inkluzji spolecznej, [w:] J. Grotowska-Leder, K. Faliszek (red.), Ekskluzja i inkluzja społeczna. Diagnoza - uwarunkowania - kierunki działań, Akapit Wydawnictwo Edukacyjne, Toruń

Rollnik-Sadowska E., 2010, Przedsiębiorczość kobiet w Polsce, Difin, Warszawa

Schumpeter J. A., 1990, Teoria rozwoju gospodarczego, PWN, Warszawa

Sidor-Rządkowska M., 2006, Kompetencyjne systemy ocen pracowników: przygotowanie, wdrażanie i integrowanie z innymi systemami ZZL, Oficyna Ekonomiczna, Kraków 
Szafraniec K., 2011, Młodzi 2011, Raport, Warszawa

Szlendak T., 2010, Socjologia rodziny, Wydawnictwo Naukowe PWN, Warszawa

Turowski J., 2001, Socjologia. Mate struktury społeczne, Towarzystwo Naukowe Katolickiego Uniwersytetu Lubelskiego, Lublin

Wachowiak P., 2007, Ksztaltowanie umiejętności przedsiębiorczych, [w:] P. Wachowiak, M. Dąbrowski, B. Majewski (red.), Kształtowanie postaw przedsiębiorczych a edukacja ekonomiczna, Wydawnictwo Akademii Ekonomicznej, Warszawa

Wasielewski K., 2006, Drogi „,do” $i$ „,od” wiejskiej inteligencji, [w:] K. Szafraniec (red.), Kapitat ludzki i zasoby społeczne wsi, Instytut Rozwoju Wsi i Rolnictwa Polskiej Akademii Nauk, Warszawa

Weber M., 1994, Etyka protestancka a duch kapitalizmu, tłum. J. Miziński, Wydawnictwo TEST, Lublin

Zioło Z., 2012, Miejsce przedsiębiorczości w edukacji, [w:] Rola przedsiębiorczości w edukacji, ser. Przedsiębiorczość - Edukacja, nr 8, red. Z. Zioło, T. Rachwał, Zakład Przedsiębiorczości i Gospodarki Przestrzennej Instytutu Geografii Uniwersytetu Pedagogicznego w Krakowie, Wydawnictwo Nowa Era, Warszawa-Kraków: $10-23$

\section{Socio-cultural entrepreneurial attitudes of young people from rural areas}

\section{Summary}

The purpose of this chapter is, starting with a review of the definition of entrepreneurship, to draw attention to the factors promoting the development of entrepreneurship and show barriers to the development of entrepreneurship of young people in rural areas. Determinants can be divided into three levels of conditions relating to entrepreneurial attitudes, ie. personality traits, which provide a framework of internal conditions. The external environment consists of the macro conditions and local conditions. In this chapter I focus on the presentation of socio-cultural entrepreneurial mindset that fall within the scope of the macro-environment conditions.

Key words:

Entrepreneurship, entrepreneurial traits, determinants of entrepreneurship, youth, rural areas. 